\title{
The Influence of Nucleating Agents and Process Parameters on Phase Structure of Isotactic Polypropylene and its Copolymer with $3 \%$ Ethylene
}

Josef Jakubíček $^{1}$, Martina Hřibová ${ }^{1}$, Jaroslav Kučera ${ }^{2}$, Milena Kubišová ${ }^{1}$

${ }^{1}$ Tomas Bata University in Zlin, Faculty of Technology, Vavrečkova 275,760 01 Zlin, Czech Republic. E-mail: Jjakubicek@ft.utb.cz

${ }^{2}$ Polymer Institute Brno s.r.o., Tkalcovská 36/2, 65649 Brno, Czech Republic, E-mail: Jaroslav.kucera @polymer.cz

The homopolymer of the isotactic polypropylene (iPP) and the random copolymer of the isotactic polypropylene and $3 \%$ ethylene (iPPE) were used in this study. Isotactic polypropylene can be prepared in $\alpha, \beta$ and $\gamma$ morphological phases depending on its crystallization conditions. The phase $\beta$ content has a strong influence on mechanical, optical and thermal properties. The samples with nucleating agents (NA) $\alpha$ and $\beta$ were used. Various process parameters were used to prepare melted samples: two thicknesses and three different cooling regimes. Wide-angle X-ray scattering (WAXD) and scanning electron microscopy (SEM) were used to investigate the phase structure. The results show that iPP without nucleation agents $\left(4 \mathrm{~mm},<1^{\circ} \mathrm{C} / \mathrm{min}\right)$ has the highest crystallinity $(83.7 \%)$. The sample of iPP with $\beta$-NA $\left(4 \mathrm{~mm},<1^{\circ} \mathrm{C} / \mathrm{min}\right)$ has the highest phase $\beta(61.3 \%)$; the slower cooling regime and the higher thickness increased the crystallinity $(73.3 \%)$. iPPE with $\beta$-NA $\left(0.4 \mathrm{~mm}, 15^{\circ} \mathrm{C} / \mathrm{min}\right)$ has the lower amount of the phase $\beta(33.8 \%)$; the higher thickness and slower cooling regime decreased the amount of the phase $\beta(7.1 \%)$ however the crystalline content of iPPE $(63.7 \%)$ is increased.

Keywords: nucleation, isotactic polypropylene, crystallization

\section{Acknowledgement}

This work was supported by a grant from the internal TBU IGA / FT / 2016/005 and financed from funds for specific academic research.

\section{References}

[1] MAIER, C. CALAFUT, T.. (1998). Polypropylene - The Definitive User's Guide and Databook. William Andrew Publishing/Plastics Design Library.

[2] NATTA, G., CORRADINI, P. (1960). Structure and properties of isotactic polypropylene, Nuovo Cim. 15 (1), $40-51$

[3] TRIPATHI, DEVESH. (2002). Practical Guide to Polypropylene. Smithers Rapra Technology.

[4] [J. KANG, J. LI, S. CHEN, S. ZHU, H. LI, Y. CAO, F. YANG, M. XIANG. (2013). Hydrogenated petroleum resin effect on the crystallization of isotactic polypropylene, J. Appl. Polym. Sci. 130 (1), 25-38.

[5] LOTZ, B. (2000). What can polymer crystal structure tell about polymer crystallization processes? Eur. Phys. J. E 3 (2), 185-194.

[6] AlfOnSO, G. C., AZZURRI, F., CASTELlANO. (2001). M. J. Therm. Anal. Calorim, Vol. 66, pp. $197-207$.

[7] THANOMKIAT. P.; SUPAPHOL, P.; PHILLIP, P., R.: Influence of Different Molecular Characteristics of Synd. Polypropylene on Equil. Melting Temperature and Crystall. Behavior. Chulalongkorn University, Thailand

[8] SHANKS, R. A., TIGANIS B. E: Nucleating agents for thermoplastics, Plastics aditived: An A-Z Reference, Chapman \& Hall, London, 1998, ISBN 041272720 X

[9] KARGER-KOCSIS, J.: Polypropylene - An A-Z Reference, Kluwer Publishers, Dordrecht.1999

[10]ELIAS, H. G.: An introduction to plastics - 2nd completely rev. ed.: Wiley-VCH, 2003, 387 s. ISBN 3-527-296026

[11]HOFFMAN, J. D.; DAVIS, G. T.; LAURITZEN Jr., J. I.; Treatise on Solid State Chemistry Vol. 3, Crystalline and Noncrystalline Solids, N. B. Hannay, ed., Plenum, New York, 1976 Chap. 7

[12]BRUCKNER, S., PHILLIPS, P.J., MEZGHANI, K., MEILLE, S.V. (1997). On the crystallization of $\gamma$-isotactic polypropylene: a high pressure study, Macromol. Rapid Commun. 18 (1), 1-7.

[13]LU, Q., DOU, Q. J. (2009). Polym. Res., 16, 555

[14]J. KANG, J. CHEN, Y. CAO, H. LI, (2010). Effects of ultrasound on the conformation and crystallization behavior of isotactic polypropylene and $\beta$-isotactic polypropylene, Polymer 51 (1), 249-256. 
[15]Q. LU, Q. DOU. (2009). $\beta$-Crystal formation of isotactic polypropylene induced by N,N0- dicyclohexylsuccinamide, J. Polym. Res. 16 (5), 555-560.

[16]ALEXANDER, L. E. (1969). X-Ray Diffraction Methods in Polymer Science. New York: Wiley-Interscience, 1969. $582 \mathrm{p}$.

[17]RYBNIKÁŘ, F. (1985), Selective etching of polyolefines. I. Isotactic polypropylene. J. Appl. Polym. Sci., 30: 1949-1961. doi:10.1002/app.1985.070300513

\section{Paper number: M201621}

Copyright @ 2016. Published by Manufacturing Technology. All rights reserved. 